\title{
Peering through the portal: COVID-19 and the future of agriculture
}

\author{
Curt Meine ${ }^{1}$
}

Accepted: 21 April 2020 / Published online: 18 May 2020

(c) Springer Nature B.V. 2020

Day \#25 of my sheltering-in-place. I set off on my daily sanity-conserving hike up the bluff behind my home in southwest Wisconsin. A muffled buzz comes from beneath the layer of duff on the ground. As I pause to listen, the red oak leaves rustle from below. The sunny spring afternoon has warmed the thin soil on the open south-facing slope. After some struggle, a plump bumblebee crawls over the threshold of its mini-burrow. The logy bee flexes its wings for a few seconds, lifts itself up and out, performs a few loops around my head, then zips off in search of early buttercups and pasque flowers. She has emerged into a landscape not so different from the one she withdrew from 5 months ago, but whose human community, at least, has dramatically changed.

Sooner or later we temporarily self-isolating humans will emerge from our burrows. Physically and ecologically our landscapes will look and function pretty much as they did pre-pandemic. But we will see them differently. The COVID19 virus has already altered the political, economic, and psychological lenses through which we perceive the world and our lives within it. Since the turn of the twenty first century, the term Anthropocene has been widely deployed-touted by some, abjured by others-to highlight the outsize impact our species has on the rest of nature. COVID-19 is a hard reminder that, however much humans have modified the living world, we hardly control it. We live in, have always lived in, and will always live in the Microbocene. Our lives at the (supposed) top of the biotic heap rest upon, and are in constant communion with, the foundations of microbial life. Consider us reminded.

"The pandemic is a portal," writes the Indian novelist and activist Arundhati Roy (2020) in a much-shared

This article is part of the Topical Collection: Agriculture, Food \& Covid-19.

\section{Curt Meine}

curtmeine@gmail.com

1 Aldo Leopold Foundation and Center for Humans and Nature, Prairie du Sac, USA commentary. "Historically, pandemics have forced humans to break with the past and imagine their world anew. This one is no different. It is a portal, a gateway between one world and the next." Once the COVID-19 incidence curves flatten, we will consider lessons learned and imagine futures unfolding. All the interconnected systems that define our lives will be fair game: social, economic, political, legal, financial, energy, health care, transportation, communication, ecological, climate-and agricultural. And among all these, our agricultural and food provisioning systems are unique. They sit at the very nexus. All systems intersect at the exact point where we take food into our bodies.

The pandemic has brought that lesson home in new and intimate ways. From the disrupted and converted ecosystems of the world, to the world's wet markets and crop fields and confined livestock facilities, through sprawling global supply and distribution chains, to local stores and restaurants, backyard gardens and kitchens, we live with the pandemic's causes and manifold effects. At every moment, in every place, we are bound to the earth and to one another via our food systems. Food access and security invariably entail matters of human health and nutrition, soil health, biodiversity, and social justice. COVID-19 may in fact have the effect of removing the distorting lenses from our eyes, allowing us to face these realities more clearly. A meme of the day makes the point: celebrities and politicians are not essential workers; farmers, farm workers, truck drivers, and grocery store clerks are.

What will agriculture look like on the other side of the portal, though our altered lines of vision? Although we are still far from emerging, we can anticipate that the answer will essentially involve the very meaning of resilience. Will we assume a narrow definition and seek simply to reconstitute pre-pandemic agriculture and food systems, with all their economic drivers and perverse incentives, big and brittle institutions, and environmental externalities? Or will we see resilience in the broadest sense, seize the opportunity that has been forced upon us, and forge a new and different path? Our answers will reflect how well we have absorbed 
the lessons of this experience, and how deeply invested we are in the past or the future.

Before COVID-19, modern American agriculture was already facing a stark choice. In 1945 Wisconsin's visionary ecologist and conservationist Aldo Leopold (1945) peered through the portal of his own times. He wrote, looking into a post-World War II future, "It was inevitable and no doubt desirable that the tremendous momentum of industrialization should have spread to farm life. It is clear to me, however, that it has overshot the mark, in the sense that it is generating new insecurities, economic and ecological, in place of those it was meant to abolish." Seventy-five growing seasons later, our technological cleverness has allowed us to produce cheap food with expensive consequences: compromised human health and nutrition, declining soil and water quality, loss of pollinators and other forms of biodiversity, a share of responsibility for climate disruption, hollowed-out rural communities and local economies, and our politically tragic urban-rural divide. In my part of the world, Wisconsin's iconic family dairies were already in crisis before the virus due to low prices, the advent of large confinement operations, and over-production and flat consumption of milk, even while facing uncertainties associated with climate change. Now dairies are dumping excess milk and face extinction.

Before COVID-19, then, the challenge was clear: we have to change our agricultural systems to meet multiple sustainability goals simultaneously. Now that challenge is unavoidable. We can and must produce healthy and nutritious food for all; but we must also improve soil health, filter and clean our surface waters and groundwater, ameliorate coastal dead zones, restore biodiversity, reduce greenhouse gas emissions and sequester carbon, foster beauty, sustain rural communities, improve farm labor conditions, and revive local economies. Enhancing food security was on that list before COVID-19, but now it is palpable and urgent. And in pursuing all these complex and interconnected goals, we have the opportunity through our agricultural systems to bring people together along the rural-urban spectrum. In reimagining and reforming our agricultural systems, we may grow not only the food we need, but the shared civic space our democracy desperately requires. As ethnobotanist and conservationist Gary Paul Nabhan writes in Food from the Radical Center (2018), "It is where we can start healing the wounds in ourselves, in our communities, and on the land."

What will this look like on the land? Part of the point is that it will-and will need to-look different in different places, across different landscapes and ecosystems, and from rural to suburban to urban lands. In the American Midwest where I live, it will mean many things. But across the landscape, it will entail a general move away from the familiar expanses of simplified, input-intensive, annual monocultures aimed at global industrial markets, and toward more diverse, multi-functional, perennial polycultures that serve local and regional foodsheds. As University of Wisconsin-Madison agroecologist Randy Jackson (2020) writes, "Transitioning to this type of agriculture requires us to re-envision what we want and expect from our working lands, from the people who manage them, and from the landscapes in which they are embedded."

As we cross the threshold and come back into the changed world beyond our burrows, we can be encouraged. Long before this latest novel coronavirus spilled over to disrupt the global socio-ecological system, creative farmers, food processors, scientists, food justice and food sovereignty advocates, nutritionists, restaurateurs, and everyday consumers were making the move toward more resilient and regenerative food systems. We have a storehouse of know-how, experience, and working examples to grow from. But just as COVID-19 has shaken our systems in unprecedented ways, the transition will require unprecedented will, determination, and leadership. Business-as-usual cannot be an option. The next world is calling to us through the portal.

\section{References}

Roy, A. 2020. The pandemic is a portal. Financial Times (3 April2020). https://www.ft.com/content/10d8f5e8-74eb-11ea-95fe-fcd27 4e920ca. Accessed 10 May 2020.

Leopold, A. 1945. The outlook for farm wildlife. In Transactions of the Tenth North American Wildlife Conference, 165-168. Washington, D.C.: American Wildlife Institute. http://digicoll.library.wisc.edu/ cgi-bin/AldoLeopold/AldoLeopold-idx?type $=$ turn $\% 26 \mathrm{id}=\mathrm{AldoL}$ eopold.ALReprints2\%26entity=AldoLeopold.ALReprints2.p0245 $\% 26$ isize $=$ M\%26pview=hide. Accessed 10 May 2020.

Jackson, R. 2020. A vision for agriculture. Aeon. https://aeon.co/ essays/our-grasslands-have-been-poisoned-by-intensive-farmi ng. Accessed 10 May 2020.

Publisher's Note Springer Nature remains neutral with regard to jurisdictional claims in published maps and institutional affiliations.

Curt Meine is a writer, environmental historian, and conservation biologist. He serves as Senior Fellow with the Aldo Leopold Foundation and withthe Center for Humans and Nature, and as an Adjunct Associate Professor at the University of Wisconsin-Madison. His most recent book is The DriftlessReader (University of Wisconsin Press, 2017). 